City University of New York (CUNY) CUNY Academic Works

\title{
The Semantic Difference Between Italian vi and ci
}

Joseph C. M. Davis

CUNY City College of New York

\section{How does access to this work benefit you? Let us know!}

More information about this work at: https://academicworks.cuny.edu/cc_pubs/460

Discover additional works at: https://academicworks.cuny.edu

This work is made publicly available by the City University of New York (CUNY).

Contact: AcademicWorks@cuny.edu 
The Semantic Difference Between Italian vi and $c i$

Joseph Davis

The City College of New York

Cite as: Davis, Joseph. The Semantic Difference Between Italian vi and ci. 2017. DOI 10.1016.

Lingua (in press)

\section{Introduction}

In much twentieth-century literary Italian, and up to the present day, a semanticpragmatic opposition obtains between the adverbial clitics vi and ci (both typically glossed 'there'). Logic-based claims to the contrary notwithstanding, vi and $c i$ are not synonymous. The difference between them has to do with the degree to which a writer restricts, or focuses, a reader's attention on the space associated with an event. The term space is understood here as encompassing both physical place (locatives) and other circumstantial conditions (complements) that are pertinent to narrated events (verbs) with their participants (subjects and objects). The term restricted has to do with a writer's commentary as to the degree to which that "space" is differentiated from other, possibly not even defined, space. This opposition operates not at the level of syntax but in discourse. The two meanings function to direct attention onto the relevant conceptual space for each event in a narrative. As such, the meanings provide subjective commentary rather than literal description. The hypothesis accounts for patterns of usage. It is a synchronic statement independent of whatever process of grammaticalization may have led to the current state.

Diagram 1 represents the opposition. 
Diagram 1. The Grammatical System of Restrictedness of Space

\begin{tabular}{|l|l|l|l|}
\hline Restrictedness & $\mathcal{C}$ & MORE & $v i$ \\
\cline { 3 - 4 } of Space & $\mathcal{L}$ & LESS & $c i$ \\
\hline
\end{tabular}

The two meanings, MORE, signaled by $v i$, and LESS, signaled by $c i$, are relative. The terms need to be understood not as absolutes but as essentially equivalent to the terms MORE RESTRICTED and LESS RESTRICTED. The meanings are, moreover, evaluative and subjective on the part of the language-user, not straightforwardly descriptive of a literal physical scene, not sensitive to truth-value.

The term meaning here is used in the technical sense that it has in Columbia School linguistics. In that framework, as here, linguistic meaning is distinguished not only from real-world scene, with its connection to truth-value, but also to what is called message. A meaning is the constant, encoded semantic content of a signal that is part of the linguistic system of a language; such are the meanings and signals of Diagram 1. By contrast, message is the myriad, dynamic, and holistic communication that language-users may imply and infer through their pragmatic use of those meanings in situational context. The goal of the analyst in this framework is to hypothesize signals and their meanings; an understanding of message helps to do that. Examples below will illustrate this connection between meaning and message as the hypothesized meanings of $v i$ and $c i$ contribute to whatever message is to be inferred on each occasion of language use. 
A Columbia-School approach is particularly well suited to address a problem involving an apparent synonymy that is based on universal, logical truth-value. For one thing, Columbia School explicitly aims to account for the observed distribution of forms in discourse, and so the direct evidence of forms in discourse is paramount. This emphasis entails beginning with the assumption of one-form - one-meaning, until, that is, analysis forces the postulation of homonyms. In terms of the present study, analysis begins with the expectation that, for instance, $c i$ in locative contexts is not a separate grammatical form from $c i$ in existential contexts, and with the expectation that the forms $v i$ and $c i$, being phonologically distinct, will have semantically distinct content. ${ }^{i}$ Too, Columbia School meanings-while, to be sure, sometimes having a strongly referential component—have essentially to do with communication as opposed to, say, logic or even cognition. Thus they lend themselves much better to problems involving subjective commentary than do universalist logic-based primitives. Finally, Columbia School makes much of what it calls the human factor in language structure and use, such that the structured meanings and the pragmatic uses of them in communication reflect peculiarly human interests and biases, rather than being objectively referential and descriptive. These theoretical positions, while always operative in Columbia School, are especially important in the analysis of the distribution of the Italian clitics $v i$ and $c i$.

See Diver (1995/2012) for a definitive statement, including the three-way distinction meaning/message/scene. For introductions to Columbia School, see Huffman $(2001,2012)$. For anthologies and commentaries, see Contini-Morava and 
Goldberg (1995); Reid, Otheguy, and Stern (2002); Contini-Morava, Kirsner, and Rodríguez-Bachiller (2004); and Davis, Gorup, and Stern (2006).

A concise illustration of the communicative difference between between $v i$ and $c i$ can be seen in the following passage from Italo Calvino's 1952 fantastical novel Il visconte dimezzato 'The Divided Viscount.' The title refers to a young nobleman who, at war in the Seicento, gets blasted in half, and both halves survive. In the episode from which Example (1) is taken, a young girl tending her goat and her duck in the countryside seeks shelter from a storm. (Both forms may be apocopated before vowels, thus $v^{\prime}$ and $c^{\prime}$, respectively.)

1. Seppe che lí vicino era una grotta, seppur piccola, una cavità appena accennata nella roccia, e vi si diresse. Vide che ne usciva uno stivale frusto e rabberciato, e dentro c'era rannicchiato il mezzo corpo avvolto nel mantello nero. (Calvino 76)

vi si diresse there self directed-3sg

ci era rannicchiato there was-3sg crouched

'She knew that there was a cave nearby, though small, an opening barely hinted at in the rock, and she headed towards it (or 'there' vi). She saw that a 
worn-out and patched-up boot was sticking out of it, and that crouched inside ('there' $c i$ ) was the half body wrapped in the black cloak.'

Here, both $v i$ and $c i$ refer to the same entity, a cave, but one of them, $v i$, indicates a more severe restriction of the relevant space represented by that entity. Of all the places in the countryside where the girl might go, she goes just 'there.' When the girl has the whole countryside at her disposal, the cave is effectively a point, to which she specifically directs herself; thus vi for the cave. Once the girl is standing in front of the cave, however, and peering into it (dentro), the same cave is effectively a three-dimensional space somewhere in which the dark-cloaked recumbent body of the half viscount can be spied; thus ci for the cave. In other words, relative to the wide-open space of the countryside, the cave is a precise destination (vi), not just anywhere, while relative to the three-dimensional space within the cave, the location of the viscount could have been anywhere (ci). To ignore the semantic distinction between vi and $c i$ would be to remain oblivious to a change of perspective as the episode progresses.

\section{Previous treatment: Synchronic synonymy}

Diachronically, vi derives from the Latin ibi 'there'; ci derives from ecce hic 'lo here' (Pei 1941: 89-90). (See below on the homonymous clitic personal pronouns vi 'you$\mathrm{pl}^{\prime}$ and $c i$ 'us.')

As reported by Russi (2008: 57-61), vi, relative to $c i$, "has an extremely marginal status in contemporary Italian," with "a very low frequency of occurrence" 
and a use "restricted to highly formal, essentially written, registers." ${ }^{\text {ii }}$ In Russi's view, these differences in frequency and register would be the clitics' only synchronic differences; otherwise, they are comparable. Vi and ci may both be "locative clitics," but they "no longer carry any deictic reference (ci 'here' $\sim v i$ 'there' ...)." Nor do the two encode any distinction between locatives of state ('at,' 'in') or of motion ('to,' 'from,' 'by,' 'across'). Too, both clitics equally can be interpreted as "topic/subject matter complements," such as in pensarvi / pensarci 'think about (or 'to') something' or aderirvi / aderirci 'agree to / comply with something.' And presumably (though here Russi cites only examples with ci), either clitic "pronominalizes comitative ..., instrument ..., and matter complements ..., which are headed by the preposition con 'with,'” as in ci ho taligato il basilico 'I cut the basil with them (= scissors).' In other words—to put it plainly—considerations of such canonical linguistic categories are irrelevant. Russi, indeed, goes so far as to claim that $v i$ and $c i$ "have become fully synonymous." It is the aim of this paper to challenge that claim of full synonymy, which can only be based on the logical notion of truth value, not on communicative value. That is, the claim of synonymy is based on the propositional sentence, not on communicative discourse. The claim here is that, in modern literary Italian, there is a meaningful distinction between $v i$ and $c i$.

\section{A plausible alternative treatment: Markedness}

As an alternative to a hypothesis that vi and $c i$ bear meanings that are mutually oppositional within one semantic substance (Dgm. 1), an approach based on markedness would also challenge the view that the two clitics are synonymous. 
However, a hypothesis based on markedness has nevertheless been rejected here for analytical reasons. Suppose that vi were held to be marked for Restrictedness of Space, with the meaning RESTRICTED, and $c i$ unmarked for Restrictedness of Space. Such a hypothesis would be compatible with a distribution where all tokens of $v i$ involve restricted space while tokens of $c i$ sometimes involve such restricted space, sometimes involve unrestricted space, and sometimes have nothing to do with the matter of restriction of space at all. (Compare the way both vi and $c i$ are unmarked, as it were, for gender, number, case role, time, aspect, etc.) Yet, as the examples below will show, both meanings have to do with Restrictedness of Space, and one is relative to the other. Particularly, $c i$ is not indifferent to the matter of Restrictedness of Space; rather, ci signals that that substance is relevant and that the degree of restrictedness is said (by the writer) to be LESS than would have been the case if $v i$ had been chosen instead.

\section{Personal pronouns vi and $c i$}

Contemporary Italian evidently has personal pronominal clitics that are homonymous with the so-called locative clitics: vi 'you-pl' and ci 'us.' Dichronically, vi 'you-pl' may well have derived ultimately from Latin vobis and thus may have always occupied a distinct place in the grammar. But it appears that modern ci 'us' is a replacement for an earlier $n i<$ nobis, and that this substitution took place by "a curious process of analogy" involving the homophony of the two clitics vi and the phonetically similar $m i$ 'me' and $t i$ 'you-sg' (Pei 1941: 86-87). Russi (2008: 60) agrees. 
In actual contextualized discourse, it is practically always possible, despite homonymy (including clitic position; cf. Lepschy \& Lepschy 1988: 212), to ascertain which clitic is represented by a certain token of $v i$ or of $c i$; therefore, it seems legitimate to treat $v i$ 'you-pl' and $c i$ 'us' as essentially irrelevant to the present analysis of $v i$ 'there' and $c i$ 'there.' The position taken here is that modern Italian has two separate systems: a system of grammatical oppositions involving person and number signaled by mi 'me,' $t i$ 'you-sg,' ci 'us,' vi 'you-pl,' and the third-person clitics (not diagrammed in this paper); and a system of grammatical opposition between $v i$ 'there' and $c i$ 'there' (Diagram 1).

\section{Quantitative evidence}

The examples throughout this paper have been selected, from among many, in order to illustrate the analytical point, but the examples are not atypical. Discourse exhibits overall patterns that lend quantitative support to the hypothesis of Restrictedness of Space. Four predictions, and four counts, are presented below.

First: If a thing is relatively well identified, then the location of its activity will tend to be known, and no question of relative Restrictedness of Space will need to be introduced. By contrast, if a thing is relatively unknown, then its location will tend to be unknown, and the semantic substance of Restrictedness of Space will be more likely to be introduced by the writer at that point in the discourse. This is not, obviously, a matter of rule but of tendency. Examples (2) and (3) will illustrate, respectively.

Example (2): a relatively known thing, quello 'that,' without vi/ci: 
2. il desiderio di Fabo era quello di tornare, in qualche modo, nella sua Goa. (repubblica.it, accessed April 8, 2017)

Fabo's wish was (that) to return, somehow, to his Goa.

Example (3): a relatively unknown thing, qualcosa 'something,' with vi/ci:

3. Se c'era qualcosa di buono da scoprire tra i giovani di Sanremo, si concentrava nel talento del cantautore. (repubblica.it, accessed April 8, 2017)

If there was something good to discover among the young men of San Remo, it resided in the talent of the singer-songwriter.

Il desiderio di Fabo 'Fabo's wish' in (2) is more fully specified than qualcosa di buono 'something good' in (3); a 'wish' is one kind of 'something.' Correlating with that difference in specification is the absence (era) versus the presence ( $c^{\prime} e r a$ ) of a signal of Restrictedness of Space. Example (2) begins with not just 'something' but specifically 'Fabo's wish,' and then that 'wish' is identified even further as 'to return to Goa.' The writer does not need Restrictedness of Space to help to narrow down the possibilities of what it being referred to here. By contrast, Example (3) begins not with something specific established perhaps earlier in the context—such as, say, 
la potenzialità professionale 'professional potential'—but instead with a virtually wide-open cognitive space, and then (3) asserts the possibility of the existence of 'something good.' A signal of Restrictedness of Space (ci) serves to fix the possibilities of what is being referred to: not, say, 'professional potential' specifically, and not just 'something good' in the universe generally, but 'something good' with regard to 'the young men of San Remo.' Such differences in interpretation are codified in the grammatical tradition as, respectively, subject with identificational predicate (2) and existential construction (3). Here, by contrast, those differences in interpretation, to the extent that they apply, are held to be not $a$ priori primitives but instead the product of the interaction of grammatical meaning and lexicon in context.

In order to determine the generality of this pattern, the web site of an Italian newspaper, La Repubblica, was mechanically searched for the following exact phrasesiii:

- c'è qualche cosa, v'è qualche cosa, vi è qualche cosa, all of which can be loosely glossed 'there is some thing' or 'some thing is there' (i.e., indefinite thing with clitic); and è qualche cosa, which can be glossed 'some thing is' or 'is some thing' (i.e., indefinite thing without clitic);

- c'è la/quella/questa cosa, v'è la/quella/questa cosa, vi è la/quella/questa cosa, all of which can be glossed 'there is the/that/this thing' or 'the/that/this thing is there' (i.e., definite thing with clitic); and è la/quella/questa cosa, which can be glossed 'the/that/this thing is' or 'is the/that/this thing' (i.e., definite thing without clitic). 
Table 1 gives the results. Absolute figures are given, along with (in parentheses) proportions, for ease of comparison.

Table 1. Restrictedness of Space correlated with indefiniteness of a thing

\begin{tabular}{|l|r|c|c|c|c|}
\hline \multirow{2}{*}{} & \multicolumn{2}{|c|}{$v i / c i$} & & \multicolumn{2}{c|}{ neither } \\
\cline { 2 - 6 } & $n$ & $(p)$ & & $n$ & $(p)$ \\
\hline qualche cosa 'some thing' & 368 & $(.69)$ & & 166 & $(.31)$ \\
\hline $\begin{array}{l}\text { la/quella/questa cosa } \\
\text { 'the/that/this thing' }\end{array}$ & 162 & $(.02)$ & & 9,140 & $(.98)$ \\
OR=125 \\
\hline
\end{tabular}

Source: repubblica.it, accessed July 19, 2017

The indefinite qualche cosa 'some thing' tends strongly to co-occur with vi/ci, while the definites la/quella/questa cosa 'the/that/this thing' tend strongly to occur without either clitic. This correlation supports the hypothesis of Restrictedness of Space.iv

By the same token, if a person is relatively well identified, then the location of his activity will tend to be known, and no question of relative Restrictedness of Space will need to be introduced. By contrast, if a person is relatively unknown, then his location will tend to be unknown, and the semantic substance of Restrictedness of Space will be more likely to be introduced by the writer at that point in the discourse.

Example (4): a relatively known person, lui 'he,' without vi/ci: 
4. "Il protagonista era lui [Paolo Villaggio] ma lasciava spazio al mio personaggio del Commissario Auricchio." (repubblica.it, accessed July 19, 2017)

"He [Paolo Villaggio] was the protagonist, but he made space for my character Commissioner Auricchio."

Example (5): a relatively unknown person, qualcuno 'someone,' with vi/ci:

5. Che il papà aveva fatto solo il suo lavoro e non aveva nulla di cui vergognarsi, anche se c'era qualcuno che la pensava diversamente. (repubblica.it, accessed April 8, 2017)

For the father had only done his job, and he had nothing to be ashamed of, even if there was someone who thought differently.

Again in order to determine the generality of this pattern, the web site of $L a$ Repubblica was searched for the following exact phrases:

- c'è qualche persona, v'è qualche persona, vi è qualche persona, all of which can be loosely glossed 'there is some person' or 'some person is there' (i.e., indefinite person with clitic); and è qualche persona, which can be glossed 'some person is' or 'is some person' (i.e., indefinite person without clitic); 
- c'è la/quella/questa persona, v'è la/quella/questa persona, vi è la/quella/questa persona, all of which can be glossed 'the/that/this person is there' (i.e., definite person with clitic); and è la/quella/questa persona, which can be glossed 'the/that/this person is' or 'is the/that/this person' (i.e., definite person without clitic).

Table 2 gives the results:

Table 2. Restrictedness of Space correlated with indefiniteness of a person

\begin{tabular}{|l|r|c|r|r|r|}
\hline \multirow{2}{*}{} & \multicolumn{2}{|c|}{$v i / c i$} & & \multicolumn{2}{c|}{ neither } \\
\cline { 2 - 6 } & $n$ & $(p)$ & & $n$ & $(p)$ \\
\hline qualche persona 'some person' & 12 & $(.92)$ & & 1 & $(.08)$ \\
\hline $\begin{array}{l}\text { la/quella/questa persona } \\
\text { 'the/that/this person' }\end{array}$ & 92 & $(.04)$ & & 2,117 & $(.96)$ \\
\multirow{2}{*}{ OR=276 } \\
\hline
\end{tabular}

Source: repubblica.it, accessed July 19, 2017

The indefinite qualche persona 'some person' tends strongly to co-occur with vi/ci, while the definites la/quella/questa persona 'the/that/this person' tend strongly to occur without either clitic. The correlation supports the hypothesis of Restrictedness of Space.

The two counts above demonstrate that indefinites (with third-person singular copula $\grave{e}$ 'is') tend to co-occur with the adverbial clitics $v i / c i$, while definites tend to occur without adverbial clitic. This correlation supports the hypothesis that the semantic substance invoked by vi/ci has to do with Restrictedness of Space, since 
relatively known things and persons will tend to have relatively known locations, compared with relatively unknown things and persons. With unknown things and persons, the space in which that thing or person exists will often need to be somehow limited (MORE or LESS) if the writer's communicative goal at that point in the discourse is to be achieved: if the narrative relevance of that thing or person is in any way to be drawn. ${ }^{v}$

The two counts that follow relate to the opposition of value between the two meanings of the system, MORE and LESS Restricted.

Grammatical aspect offers a way to show empirically a large-scale narrative effect that later will be examined in context: that of thematic importance. In terms of grammatical morphology, as is well known, foregrounded events tend to have perfective aspect, while backgrounded events tends to have imperfective aspect. Reid (1978) for French and Gorup (1987) for Serbo-Croatian propose that perfective morphology signals a higher degree of attention on an event, while imperfective morphology signals a lower degree of attention on an event. In view of usage of analogous forms in Italian texts, a similar hypothesis could be assumed for Italian as well.

Examples (6) and (7) will illustrate the co-occurrence of HIGH-Focus perfective aspect with MORE Restricted Space and of LOW-Focus imperfective aspect with LESS Restricted Space.

Example (6): perfective aspect co-occurring with vi: 
6. Senz'alcuna ragione plausibile, una notte andò fin sotto le case di Pratofungo che avevano i tetti di paglia e vi lanciò contro pece e fuoco. (Calvino 47)

Without any plausible reason, one night [the evil half-viscount] went right up to the houses in Mushroom Meadow that had straw roofs and tossed pitch and fire onto them (vi).

To make the roofs catch fire and wreak his havoc, the evil half-viscount, the main character, needs to toss the pitch and fire exactly and deliberately onto the roofs: RESTRICTED Space.

Example (7): imperfective aspect co-occuring with ci:

7. Il Buono andava per i campi e vedeva vecchi ugonotti scheletriti zappare sotto il sole.

- Avete una brutta cera, - disse a un vecchio con la barba tanto lunga che ci zappava sopra, - forse non vi sentite bene? (Calvino 87)

The Good One wandered through the fields and saw old, skeletal Huguenots hoeing in the sun.

"You look ill," he said to one old man with a very long beard who was hoeing over it (ci). "Do you not feel well?" 
The old man, a very minor character, is hoeing somewhere in the fields. His beard is so long that he inadvertently hits it with his hoe while he is trying to hoe the field. It is not his target.

It can be predicted, then, that the Italian perfective aspect, the passato remoto, will tend to co-occur with MORE Restricted Space, signaled by vi, while the imperfective aspect, the imperfetto, will tend to co-occur with LESS Restricted Space.

Table 3 presents the results of a count.

Table 3. Restrictedness of Space correlated with verbal aspect

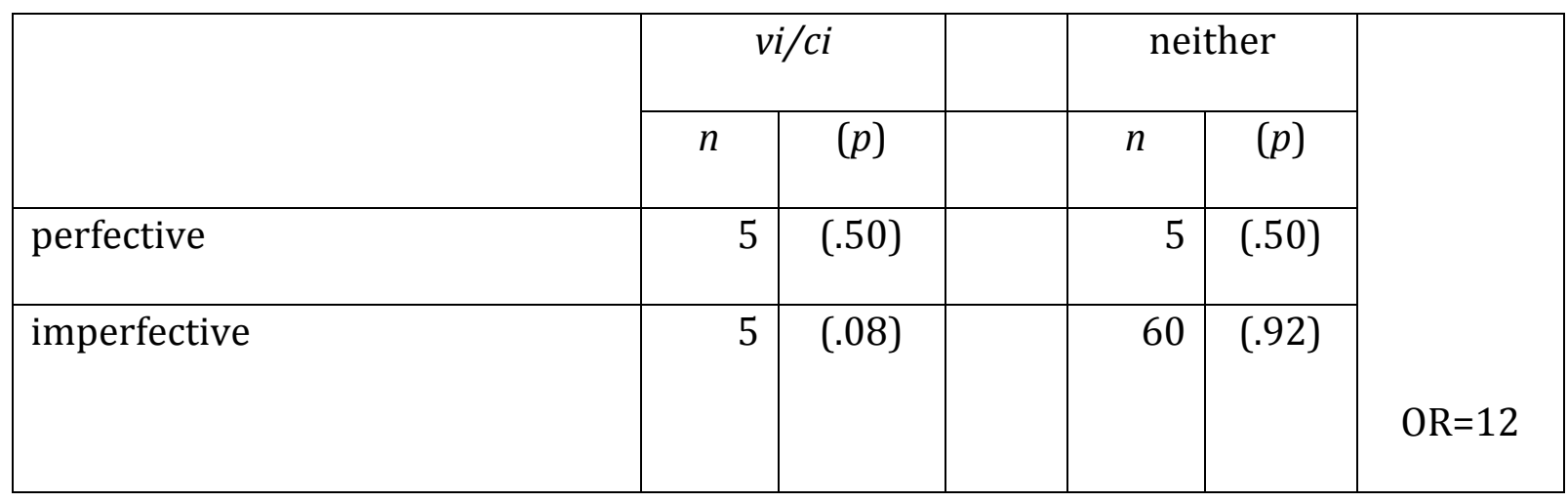

Sources: Calvino, Cescatti, Ronconi, Tabucchi

In Italian, the perfective aspect, typically providing the main narrative line, tends to co-occur with vi relative to the imperfective aspect, which, typically providing background information, tends to co-occur with ci. The correlation supports the hypothesis that vi means MORE Restricted Space and ci means LESS Restricted Space.

So while there is a correlation between $v i / c i$ and the importance of the event, as indicated by verbal aspect, that is only a correlation consistent with their relative meanings, not an absolute. As even a quick review of examples in this paper will 
confirm, both $v i$ and $c i$ appear with both perfective and imperfective aspects and, indeed, with other tenses altogether. Both clitics are marked, as it were, for Restrictedness of Space, and their relative meanings factor into the observed correlation. Regardless of aspect or tense, a choice between $v i$ and $c i$ gets made. If $c i$ were unmarked, then, in contexts where space is indeed somehow restricted, the choice between the two clitics would have to be made on some basis (What?) other than Restrictedness of Space. Instead, the choice appears to be made, throughout, on the basis of Restrictedness of Space. ${ }^{\mathrm{vi}}$

A final count supporting the hypothesis of Restrictedness of Space has to do with the grammatical number of the verb to which $v i / c i$ is clitic. The communicative effect of a plural finite verb is that the entities being focused upon with respect to that event (its subject) are ENUMERATED. That is, individuals within a set are differentiated sufficiently that they can be counted (at least potentially, if not completely). By contrast, the communicative effect of a so-called singular verb is that no enumeration takes place. Either individuation is not at issue at all (as with many references to a mass, an abstraction, or an indefinite or impersonal), or else individuation stops at one discrete, whole entity and never moves beyond that one to another of its ilk.vii

This conceptualization of verb number motivates a prediction the results of which may be surprising: An event (represented by a finite verb) whose subject is discrete enough to be enumerated (i.e., a plural) will tend to be restricted enough in space so that that enumeration will be possible: To be counted, things in a set have to be individually identifiable in conceptual space. Enumeration requires 
boundedness, each individual separate from the others. To be sure, an event with a plural subject may be distributed over a vast space, but the multiplicity of its subject cognitively entails discrete micro-events. For example, the raindrops fall (with plural fall) may describe an event happening over a large stretch of land, but the plural explicitly invokes multiplicity and so a boundedness within that space. By contrast, an event whose subject is not to undergo enumeration (i.e., a "singular") will tend to occur in an unrestricted conceptual space, one that is not divided into multiple units.viii For example, the rain falls (with singular falls) may describe an event happening over a countryside every bit as large as that above, but the singular reflects a cognitive ignoring of the multiplicity that is, in reality, involved. That is, the choice of singular reflects a decision not to impose boundaries within the space. (And, of course, singular the raindrop falls also entails no enumeration from one discrete entity to another.) Here, as always, Restrictedness of Space has nothing to do with the actual physical size of the space but rather with a conception of it as being somehow bounded, separated from some other space.

Thus, it can be predicted that plural verbs will tend to occur with vi, while singular verbs will tend to occur with $c i^{\text {ix }}$ Example (8) will illustrate. A donkey cart with passengers has been traversing the famously fertile 'green Fucino Basin' (p. 62) and here enters a rougher terrain.

8. Il traino di Magascià s'interna lentamente nella valle di Pietrasecca, dapprima ampia, poi strozzata tra ripide pendici di rocce grigie bruciate dal sole. Tra le rocce, negli avvallamenti composti dai detriti delle alluvioni, vi 
sono dei campicelli coltivati a granturco e a patate, poderetti che non si misurano a ettari, ma a canne e a coppe. Sul monte si vedono altri di questi campicelli, appiccicati come cerotti. Dovunque c'è una zolla di terra coltivabile, vi sono le tracce dell'attività dell'uomo. (Silone 64-65)

Magascià's tow slowly enters into the valley of Pietrasecca, at first wide, then choked between steep slopes of gray rocks baked by the sun. Among the rocks, in the depressions composed of silt from floods, there are (vi sono) some little cultivated fields of corn and potatoes, small farms measured not in hectares but with rods and cups. On the mountain one can see more of these little fields stuck like pieces of plaster. Wherever there is (c'è) an arable clod of earth, there are (vi sono) traces of human activity.

The passage contains two instances of $v i$ and one of $c i$. Within the otherwise fertile basin, these 'little cultivated fields' are individually hemmed in by the agriculturally inhospitable rocks in the valley's depressions (vi), within which area the fields can be individuated and enumerated (sono). As in those fields, says the narrator, so too within any 'arable clod of earth' (vi), distinct from its barren surroundings, some 'traces of human activity' can be here and there identified and enumerated (sono). By contrast, the practice of cultivation exists all over the earth (c'è), 'wherever.' That is, the 'little cultivated fields' and the 'traces of human activity' exist in MORE highly restricted spaces (vi) apart from other spaces and can be ENUMERATED (sono). By contrast, earth as a cultivable environment lends itself to 
a holistic perspective (è), and cultivable areas are relatively LESS restricted within that environment (ci). The commentary amounts to this: Take whatever arable land you wish, anywhere on earth (ci); within that land-but only within the confines of that hospitable land-you can find humans scratching out a living somehow, somewhere (vi).

Table 4 presents the results of the count.

Table 4. Restrictedness of Space correlated with verb number

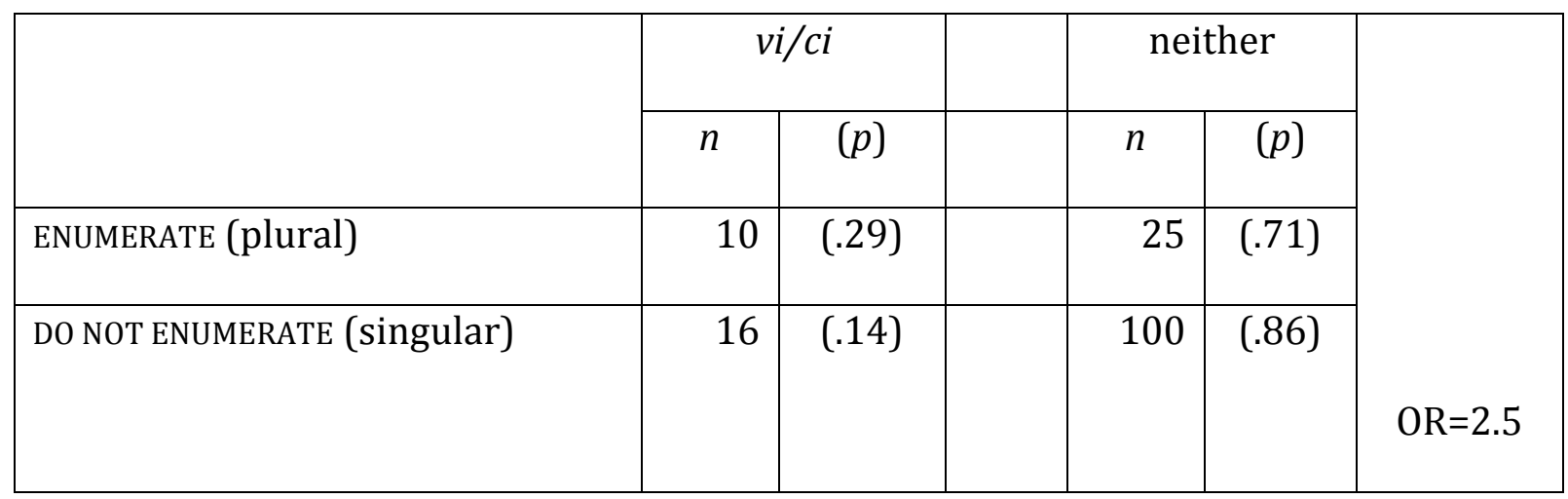

Sources: Calvino, Cescatti, Ronconi, Tabucchi

The space that is relevant to a particular event in a narrative tends to be MORE restricted (vi) when the event relates primarily to entities that are ENUMERATED (plural), and LESS restricted ( $c i$ ) when the event relates primarily to an entity that is not enumerated (a singular).

Verifiable patterns observed in authentic discourse support the hypothesis that $v i$ and $c i$ are not synonymous but differ in relative Restrictedness of Space. 


\section{Messages of place}

Although received categories such as locative and existential will be shown in this paper to be irrelevant to the distribution of vi and $c i$ and are replaced by newly hypothesized meanings for those forms, the familiar categories may be useful for purposes of presentation.

Vi and ci may refer to actual physical places, such as the 'cave' in Example (1). When they do so, the relevant consideration, as concerns the difference between them, is the relative restrictedness of that place. Examples (9) and (10) illustrate further. Pietro Spina, a young revolutionary against Fascist Italy, has returned to the rural area where he grew up but is quite sick and is in hiding. In (9), he speaks to a doctor and childhood friend who has come to help him; in (10), he responds to that friend.

9. $\quad-\ldots$ Alla polizia di Roma sono stato denunziato appena ho preso contatto con l'organizzazione, evidentemente da qualche provocatore che vi si annida.... (Silone 39)

“... I was denounced to the police in Rome as soon as I made contact with the organization [i.e., the resistance], evidently by some troublemaker who was hiding out there (vi)..."

10. $-\ldots$ Sono venuto qui, . . ., solo per consigliarti di ripartire al più presto e di tornartene all'estero, nell'interesse tuo e nostro. 
— Grazie del consiglio, ma all'estero non ci torno, ribatte Spina.

(Silone 39-40)

“... I came here ... only to advise you to go back as soon as possible and to return abroad, in your interest and ours."

“Thank you for the advice, but I'm not going back (ci) abroad," Spina responded. ${ }^{x}$

In (9), vi refers to a city in Italy, Rome, a place with relatively MORE restricted boundaries; in (10), ci refers to land 'abroad,' outside Italy, a relatively LESS restricted geographical designation.

This is not to imply that literal, physical acreage is the only relevant consideration; any kind of restriction may be relevant. In Example (11) below, from the same episode, just as in (10) above, a large area is again referenced, but now a restriction other than size of geographical space is involved.

11. - Nell'emigrazione non torno, interrompe Spina.

- Purtroppo, anche se tu volessi, non potresti tornarvi, risponde il medico. (Silone 44)

"I'm not going back into exile," Spina interrupted.

"Indeed, even if you wanted to, you couldn't go back there (vi)," the doctor replied. 
The doctor's point is that the revolutionary is too sick to travel. His sickness restricts his movement. The space-and by extension the condition of being in that space—defined by “Nell'emigrazione" 'Into exile' is off limits to Spina. Exile is a condition that is severely separated from Spina, due to his physical condition now back in Italy. The example should help to make it clear that the degree-the strength, the relevance-of the restrictedness of a space is not the same consideration as the physical size of the space.

\section{Messages of other types of conceptual spaces}

Just as with physical space, so too with other conceptual spaces-for instance complements to pensare 'think' and other mental verbs-the difference between $v i$ and $c i$ has to do with the Restrictedness of the Space. Examples (12) and (13) illustrate.

12. No, mi dissi ordinando sul ripiano una pila di piatti, la mia vita condurrà in qualche posto. Io preferivo infinitamente la prospettiva di un mestiere a quella del matrimonio; autorizzava delle speranze. C'era stata gente che aveva fatto cose: ne avrei fatte anch'io. Non sapevo bene quali. L'astronomia, l'archeologia, la paleontologia, mi avevano di volta in volta attirato, e continuavo ad accarezzare vagamente il progetto di scrivere. Ma erano progetti che mancavano di consistenza, e non vi credevo abbastanza per affrontare con fiducia l'avvenire. 
Avevo perduto la sicurezza dell'infanzia; in cambio non avevo guadagnato niente.

(Simone de Beauvoir, Memorie d'una ragazza perbene, transl. Bruno Fonzi) ${ }^{\mathrm{xi}}$

No, I told myself, arranging on the shelf a stack of dishes, my life will lead somewhere. I infinitely preferred the prospect of a career to that of marriage; it justified some hopes. There had been people who had done things; I too would do things. I didn't exactly know which things. Astronomy, archeology, paleontology had from time to time attracted me, and I continued to embrace vaguely the goal of writing. But they were goals that lacked consistency, and I did not believe in them (vi) enough to face the future with confidence.

I had lost the security of childhood; in exchange I had gained nothing.

Contrast (12), above, which has vi, with (13) below, which has ci. Example (13) comes from a newspaper article about a woman who was surprised to land a new job while she was pregnant.

13. «Appena Samuele mi ha chiamata due mesi fa l'ho avvisato subito della novità - racconta Martina - gli ho detto che ero incinta di sette mesi e che avrei partorito a breve. La loro proposta era molto interessante e io ero felicissima che mi avessero contattata ma immaginavo che l'opportunità sarebbe sfumata. Ci siamo incontrati, abbiamo scambiato qualche idea. E alla 
fine mi hanno detto che era loro intenzione offrirmi un contratto. Quasi non ci credevo».xii

"As soon as Samuele called me two months ago, I told him immediately of the news," says Martina. "I told him I was seven months pregnant and that I would soon give birth. Their proposal was very interesting, and I was very happy they had contacted me, but I imagined that the opportunity would disappear. We met and exchanged a few ideas. And in the end they told me that it was their intention to offer me a contract. I almost didn't believe it (ci)."

Absent the meaning hypothesis of Diagram 1, vi and ci in (12) and (13) would seem interchangeable, synonymous, their distribution capricious. But consideration of the hypothesized semantic contrast between $v i$ and $c i$ sheds light on the passages: In (12), with vi, the writer, Simone de Beauvoir, believes her professional prospects, though in principle large, to be limited by the fact that she is a woman. Beauvoir wrote, in French, "je n'y croyais pas assez" 'I did not believe in them enough,' French having only one adverbial clitic, $y$. And so the Italian translator needed to choose between the two options available. He skillfully brought out de Beauvoir's despair about her professional prospects by choosing $v i=$ MORE Restricted Space. The hypothetical prospects, however long the list may be, are off limits to de Beauvoir. 
By contrast, in (13), with $c i$, the speaker unexpectedly finds her professional prospects opening up just when she thought they were going to be shut down, in the final months of her pregnancy. Her choice of $c i=$ LESS Restricted Space is compatible with her enlarging belief in her prospects thanks to the job offer. The offer itself may be specific (as indeed is the viscount in the cave, of Example 1), but the conceptual space in which the offer exists is expanding. The first woman, in (12), did not believe enough in her limited possibilities; the other woman, in (13), almost could not believe her good fortune in accessing them.

\section{Thematic importance}

An appreciation of the semantic difference between $v i$ and $c i$ can inform a reader's interpretation of a text even on a large scale. If an event is relatively important in a narrative, then the space in which that event occurs will tend to be more restricted, more limited. By contrast, if an event is relatively unimportant, then the space in which that event occurs will tend to be less restricted, less limited. That is, the relevant spaces for foregrounded events in a narrative will tend to be more restricted, limited, or defined than the spaces for backgrounded events.

A climactic scene from Ignazio Silone's 1935 novel Pane e vino 'Bread and Wine' contains a striking sequence of tokens of the two clitics that illustrates this point. The elderly priest Don Benedetto, a secondary character but the very first to appear in the novel and a mentor of its hero, Spina, has spent his later years opposing the Fascist regime in Italy. But the esteem in which he is so widely held has up to this point prevented the authorities from eliminating the nuisance that he 
represents. An episode near the end of the novel recounts his assassination and can illustrate the function of the $v i / c i$ opposition to restrict space and so to narrow the reader's focus.

Don Benedetto has been called out of retirement to celebrate mass at a small country church. A young woman named Cristina goes to assist him. Example (14a) below introduces the episode (Three further excerpts, 14b-d, will follow). In (14a), the church's interior architecture is described. The description contains three sequential tokens of $c i=$ LESS Restricted Space, the effect being that the exact locations of the three architectural features, no matter how specific those locations may be-an altar at the back of the church, a fresco to the left of the altar, and a painting to the right of the altar-do not matter.

14a. Il pavimento della chiesa è ricoperto di lapidi mortuarie, del tempo in cui non esistevano i cimiteri e i morti erano sepolti nelle cripte delle chiese.... In fondo alla chiesa c'è l'altare che ha l'aspetto di un blocco disadorno di pietra, con un crucifesso di legno dipinto in nero e quattro candelieri sopra. A sinistra dell'altare $c$ 'è un affresco rappresentante l'inferno con diavoli neri di orribili e ripugnanti forme, che tormentano in varia guisa le anime dei cafoni dannati, .... Alla destra $c$ 'è una raffigurazione della leggenda dei tre morti e dei tre vivi.... Il sacrestano accende le quattro candele dell'altare e suona una campanella per annunziare l'inizio della messa. (Silone 342) 
The floor of the church is covered with memorial stones from the time when there were no cemeteries and the dead were buried in the churches' crypts.... At the back of the church ( $c i$ 'there') is the altar, which looks like an unadorned block of stone, with, above, a crucifix painted in black and four candlesticks. To the left of the altar ( $c i$ 'there') is a fresco depicting hell with black devils of horrible and repugnant shapes who are tormenting in various ways the souls of the damned countryfolk.... To the right ( $c i$ 'there') is a depiction of the legend of the three dead and the three living... The sacrestan lights the four candles on the altar and rings the little bell to announce the beginning of the mass.

Up to this point, precise locations scarcely matter: There is an altar, there is a fresco of hell, there is a depiction of a legend; it scarcely matters where in the church these typical components of ecclesiastical architecture are. Now, though, the noose tightens. The sinister purpose of the occasion begins to make itself felt, with a switch from LESS restricted $c i$ to MORE restricted $v i$.

14b. In chiesa vi sono, tra donne e ragazzi, circa una dozzina di fedeli. Don Benedetto coi paramenti sacri è ora in piedi, davanti al primo scalino dell'altare.... Don Benedetto sale sull'altare a $v i$ dispone gli oggetti che dovranno servire alla consumazione del mistero. (Silone 342) 
In church ( $v i$ 'there') are-all women and girls-about a dozen of the faithful. Don Benedetto, with the holy vestments, is standing now before the first steps of the altar.... Don Benedetto climbs up to the altar and places there (vi) the objects that will be used in the consummation of the mystery.

For the success of the impending assassination, it is important that the attendance be very sparse ('a dozen') and inconsequential ('women and children'); thus this particular country church (vi). And it is important that Don Benedetto be precisely at the altar (vi).

14c. Ogni volta che Cristina attraversa l'altare per andare da una parte all'altra, si genuflette nel centro. Or essa è alla destra e regge in una mano un'ampolla di vino e nell'altra un'ampolla d'acqua. Don Benedetto va verso di lei col calice ed essa vi versa una parte del vino e dell'acqua. (Silone 343)

Every time Cristina crosses the altar to go from one side to the other, she genuflects in the center. Now she is to the right, and she holds in one hand a cruet of wine and in the other a cruet of water. Don Benedetto goes towards her with the chalice, and she pours into it (vi) a portion of the wine and the water. 
It is important that Cristina pour the wine and water just into the chalice (vi) and nowhere else, because the poison that will kill him is in that mixture, and he will sacramentally drink it from the chalice.

14d. Don Benedetto bisbiglia sugli elementi da consacrare le parole della santificazione. Egli vi alita sopra col suo respiro. Egli confessa tre volte la sua indegnità. Poi si curva sull'altare e consuma l'ostia, alza il calice e ne beve il contenuto. (Silone 343-344)

Don Benedetto whispers over the elements to be consacrated the words of sanctification. He blows gently over them (vi) with his breath. Three times he confesses his unworthiness. Then he bends over the altar and consumes the host, raises the chalice, and drinks its contents.

Having finally gotten close enough to the sacraments to breath over them (vi) and consume them, the saintly old priest falls dead. The sequence of four tokens of $v i=$ MORE Restricted Space serves to guide the reader to focus on what is narratively important inside the church: not the locations in the church of the pieces of scenery, but the locations of the gathering of powerless witnesses, of the placement of the deadly sacraments, and—twice—of the poisoned bread and wine vis-à-vis the man who is the target of the assassination. 
In the passage, the switch from LESS restricted $c i$ to MORE restricted vi serves to direct the reader's attention to just where it needs to be if the passage is to fulfill its narrative purpose of illustrating the evil regime against which the main character, a former pupil of Don Benedetto, fights.

\section{$\underline{\text { Existential contexts }}$}

Forms of esserci (e.g., c'è 'there is,' ci sono 'there are,' c'era 'there was') are sometimes viewed as the existential construction in modern Italian. Russi (2008: 160-162) considers esserci the "presentational/existential predicate" with "fully grammaticalized status." Russi notes that forms with vi are now quite rare.

Example (15) illustrates what might be considered a typical existential:

15. Ci sono azioni che si compiono cosí d'impulso, azioni qualsiasi senza valore, che però poi dànno origine a un cambiamento nella nostra vita e nella vita di coloro che hanno relazione con noi. (Berto 12)

There (ci) are actions that are taken so impulsively—whatever unimportant actions - which, however, then give rise to a change in our life and in the lives of those who have relations with us.

In (15), the existence of impulsive actions taken by humans is indeed being asserted. 
Actually, examples of both $c i$ and vi that can be viewed as existentials still occur, even if one is more frequent than the other. ${ }^{\text {xiii }}$ In Examples (16) and (17) below, features of two islands in the Azores are described.

16. Il dio del Rimpianto e della Nostalgia è un bambino dal volto di vecchio. Il suo tempio sorge nell'isola piú lontana, in una valle difesa da monti impervi, vicino a un lago, in una zona desolata e selvaggia. La valle è sempre coperta da una bruma lieve come un velo, ci sono alti faggi che il vento fa mormorare ed è un luogo di una grande malinconia. (Tabucchi 1415)

The god of Regret and Nostalgia is a boy with the face of an old man. His temple rises on the farthest island, in a valley protected by impervious mountains, near a lake, in a desolate and wild region. The valley is always covered by a light mist like a veil. There (ci) are tall beeches that the wind causes to murmur, and it is a place of great melancholy.

17. L'isola di Pico è un cono vulcanico che fuoriesce di repente dall'oceano: è nient'altro che un'alta montagna scoscesa posata sull'acqua. Vi sono tre villaggi: Madalena, São Roque e Lajes; il resto è roccia di lava.... (Tabucchi 60) 
The island of Pico is a volcanic cone that comes out suddenly from the ocean. It is nothing but a tall steep mountain placed upon the water. There (vi) are three villages: Madalena, São Roque, and Lajes; the rest is volcanic $\operatorname{rock} \ldots$

To label such examples indiscriminately "existentials" is to miss the point. Yes, the existence of the beech trees is here asserted; and yes, the existence of the villages is here asserted. But into those assertions, $c i$ and $v i$ add the element of Restrictedness of Space. In (16), $c i=$ LESS restricted might almost be translated 'scattered all throughout (the valley),' while in (17), vi = MORE restricted almost has the sense of 'perched upon it (the island).' The passage in (16) comes from a survey of the temples of the gods worshiped by the people of the Azores, each temple found on a different island in the archipelago. The point of the passage is not to specify precisely where the beech trees stand—in reality, they are probably spread outbut to evoke the general ambience of the place where the temple stands. Thus LESS restricted $c i$. The passage in (17), by contrast, comes from a chapter devoted to whales and whalers. The passage introduces the village of Lajes, which has a small whale museum that the narrator visits, traveling there with some considerable difficulty. The museum in Lajes is not easy to get to. Thus MORE restricted vi. Logically, of course, if something exists, then it exists in a space. And it is not unusual for locative forms to have existential uses; consider English there is/are, French il y a 'it has there,' and also Swahili (Contini-Morava 1976).xiv Russi (2008: 161) too admits that $c i$ in existential constructions "has not been completely 
emptied of its spatial reference in that it expresses the place or, perhaps more appropriately, the realm of presence and/or existence of a given entity." The operative consideration with existentials, as seen previously here, is the degree of restrictedness of that space. The relevant space in which a thing exists may be MORE or LESS restricted, limited or unlimited. In Example (15) above, with $c i$, the relevant space in which impulsive actions exist might be thought of as even the entire world. Even so, however, it is the human world, not the entire physical universe. In (16) above, with $c i$, the space happens to be somewhat smaller (a valley), but still, within that space the location of the beech trees is relatively imprecise. By contrast, in Example (17) above, with vi, the relevant domain in which the three villages are asserted to exist is restricted to just particular parts of the island of Pico.

Moreover, as already seen incidentally in Example (1), there is not even a requirement that vi or $c i$ be present for a statement to be considered existential. Part of Example (1) is repeated below, with this time a blank indicating absence of adverbial clitic:

Seppe che lí vicino _ era una grotta knew-3sg that there nearby __ was-3sg one cave 'She knew that there was a cave nearby'

The existence of the cave is being asserted, but neither vi nor $c i$ is present. Instead, the example contains a freestanding (non-clitic) morpheme lí 'there' giving indication of the location of the cave. 
This lack of relationship between the received notion of existential and the distribution of $v i$ and ci calls into question the analytical assumption that modern literary Italian even has an existential construction. Rather, it appears to be the case that while certain passages can indeed be interpreted as asserting the existence of something (in some space, naturally), the grammar of Italian has no mechanism specifically dedicated to serving that communicative function. Indeed, in actual text, there seems to be no clear demarcation between examples that might be classed as locative and others that might be classed as existential; there is no grammatical distinction in modern literary Italian between locative and existential.

The triplet below, Examples (18-20), illustrates the indeterminacy between existence and space, and thus the analytical irrelevance of those a priori categories. It also illustrates what is analytically valid: an opposition of substance. While an opposition of value (familiar to anyone conversant with Saussure) involves the relationship between meanings inside a given semantic substance (e.g., Dgm. 1), an opposition of substance involves the presence versus the absence of that substance altogether. ${ }^{\mathrm{xv}}$

An opposition of the substance of Restrictedness of Space is illustrated in Example (18), where the substance is first invoked, with c'e 'there is,' and then dispensed with, with è 'is.' In Examples (19) and (20), the opposition of value within the substance of Restrictedness of Space is illustrated, with $c i$ in (19) and $v i$ in (20). That is, Example (18) illustrates one type of contrast: the relevance versus irrelevance of the substance of Restrictedness of Space. Examples (19) and (20) illustrate a different type of contrast: the substance is partitioned into two values. 
Example (18) comes from the same novel as Examples $(9,10,11,14)$, concerning the anti-Fascist revolutionary Pietro Spina. But (18) occurs towards the end of the book, when Spina is holed up in a village inn, disguised as a priest. This episode presages the horrific end of the novel, which involves wolves.

18. Durante la notte continua a fioccare ininterrottamente. Al mattino il prete dorme ancora quando è chiamato da Matalena. Davanti alla locanda c'è un gruppo di cafoni e di ragazzi attorno all'asino di Sciatàp, Garibaldi, e sulla groppa dell'asino è allungato il cadavere d'un lupo ucciso nella mattinata sulla montagna dietro Pietrasecca. (Silone 358)

During the night it continues to snow uninterruptedly. In the morning the priest is still sleeping when he is called by Matalena. In front of the inn there is (c'è) a group of peasants and children around Sciatàp's donkey, Garibaldi, and on the donkey's rump is (è) stretched out the body of a wolf killed that morning on the mountain behind Pietrasecca.

Yes, there is a group of peasants, and yes, there is a dead wolf, but to view both examples merely as existentials would be to lose a meaningful distinction. From around the village, folks have gathered to view the dead wolf, and they are loosely arrayed around the body, in no particular orientation. Restriction of Space is relevant—-the spectacle has brought them there-but their Space is relatively LESS restricted (ci) as they stand around, anywhere that affords a good view. That is, 
even an example that might be labeled existential does involve some degree of Restrictedness of Space. By contrast with the presence of the peasants, the presence (the existence, $\dot{e}$ ) of the dead wolf warns of the threat posed by wolves in the area. No narrative end would be served here by either narrowing (vi) or expanding ( $c i$ ) the relevant space in which the carcass exists. The mere fact that the wolf carcass exists bodes ill for Spina and the villagers. xvi

In Examples (19) and (20) below, by contrast, there is a narrative benefit to the writers' introducing the substance of Restrictedness of Space.

In (19), the substance of Restrictedness of Space is relevant, but space is relatively LESS restricted. The passage comes from the same novel as Example (1), about the viscount Medardo who gets blown in half. In (19), the evil half returns from battle to his native castle, where his elderly father Aiolfo fondly tends birds.

19. Ma il vecchio Aiolfo, quasi prevedendo che il figlio sarebbe ritornato cosí triste e selvatico, aveva già da tempo addestrato uno dei suoi animali piú cari, un'averla, a volare fino all'ala del castello in cui erano gli alloggi di Medardo, allora vuoti, e a entrare per la finistrella [sic] della sua stanza. Quel mattino il vecchio aperse lo sportello all'averla, ne seguì il volo fino alla finestra del figlio, poi tornò a sporgere il becchime alle gazze e alle cince, imitando i loro zirli.

Di lí a poco, sentí il tonfo d'un oggetto scagliato contro le impannate. Si sporse fuori, e sul corniccione c'era la sua averla stecchita. (Calvino 32) 
But old Aiolfo, as if foreseeing that his son would return so sad and wild, had some time ago trained one of his dearest animals, a shrike, to fly to the wing of the castle where Medardo's lodgings were, then empty, and to enter through the small window of his room. That morning, the old man opened the door of the shrike's cage and followed its flight to his son's window, then came back to scatter birdseed for the magpies and titmice, imitating their trills.

A short while later, he heard the splash of an object thrown against the window. He leaned out, and on the cornice was (c'era) his little shrike.

In (19), the old man did not know exactly where the bird was once it—presumably it, but perhaps something else-had been thrown against his window: Wheresomewhere perhaps between the wings of the palace-would the bird land? Even if the old man could assume that the bird had been killed by impact, he still could not have known just where beneath his palace window the dead body might have landed. $C i=$ LESS restricted. It turns out that the bird is found dead upon a cornice, but the location of its dead body hardly matters; it might as well have been anywhere within range of the son's throw, gravity's pull, and the old man's sight.

Finally in this triplet, Example (20) comes from an account of the retreat of Italian soldiers from Russia during World War Two. The soldiers, having suffered cold and hunger for a long time, come upon an abandoned hut with a still-warm oven. 
20. Chi porta legna e chi paglia. Nella stalla vicina vi sono due pecore e un maiale. Le pecore le diamo agli altri plotoni e noi ci ammazziamo il maiale. (Rigoni Stern 115)

Some carry wood and some straw. In the stable nearby there are ( $v i$ sono) two sheep and a pig. The sheep we give to the other platoons, and we kill the pig for ourselves.

It serves the narrative purpose quite effectively to have the sheep and pig enclosed in a space that facilitates their slaughter: $v i=$ MORE restricted. The tired, hungry men do not need to go out into the snow and hunt for food; food is right there at their ready disposal.

The set of examples (18-20) can serve too as a reminder why an approach based on markedness has been rejected. There are contexts where the question of the Restrictedness of Space does not arise, and neither clitic appears. In some of these contexts, there may not even be a defined space, as at the beginning of Example (16), repeated here as (21). Such examples would probably never even be considered existential, since they have a definite subject which is then predicated.

21. Il dio del Rimpianto e della Nostalgia è un bambino dal volto di vecchio. (Tabucchi 14)

The god of Regret and Nostalgia is (è) a boy with the face of an old man. 
In other contexts, there may be a defined space, but the language-user would advance no communicative end by restricting that space to any degree, more strongly or more weakly. Most of these examples would probably never be considered existentials, though some of them could be. Such is the situation in Example (18), where a wolf's carcass occupies the space on a donkey's rump ('on the donkey's rump [there] was a wolf carcass'). No communicative end would be served by entertaining the question of where the wolf's carcass might be-scattered or wandering around somewhere? penned in somewhere? It is where it is.

On the other hand, Restrictedness of Space may be relevant. A space may be relevantly MORE restricted; such is the space in which the sheep and the pig in Example (20) are confined. Or a space may be relevantly—and relatively—LESS restricted; such are the spaces in which the peasants in Example (18) are gathered and in which the thrown body of the shrike in Example (19) might have landed.

The observed distribution of $v i$ and $c i$ would not support an analysis based on markedness.

Italian has various ways to assert the existence of something, without or with an adverbial clitic; if there is one, then which one it is-vi or $c i-$ makes a difference. There is no existential construction in Italian. 


\section{$\underline{\text { Limitations }}$}

As with any linguistic analysis that does not aim for a linguistic universal, it is an open question the extent to which this hypothesis can be applied to data outside the range investigated. Specifically, this hypothesis may not apply to earlier Italian literature. It may well not apply to all geographical varieties. It may well not apply to twenty-first-century colloquial speech. In particular, although adverbial vi is still found in newspapers, it may be virtually absent in casual speech today. If indeed certain language-users do not have adverbial vi at all, but only $c i$, then for those language-users the semantic value of $c i$ will quite possibly be different than is proposed here. Nevertheless, for the language-users examined here, it appears that $v i$ and $c i$ stand in a semantic opposition of value (MORE VS. LESS) within a semantic substance of Restrictedness of Space.

\section{Suggestions for future research}

Of course, there will always be additional examples to explicate; the peculiarities of individual examples are infinitely varied, even within a fairly homogeneous variety such as twentieth-century literary prose. Also, future research should help to decide whether it is preferable to state the meanings as MORE and LESS Restrictedness of Space or as RESTRICTED and UNRESTRICTED, even though, either way, the two systeminternal values are understood to be relative to each other. It is also possible that future research will suggest some better expression of the semantic substance involved than "Restrictedness of Space." And, as noted in an endnote, the intricacies 
of the statistical behavior of definite and indefinite reference of grammatical subject with respect to $v i$ and $c i$, internal to the system, remain to be explored.

\section{$\underline{\text { Conclusion }}$}

If, as per Diver (1995/2012: 445), what we call language is indeed an "instrument of communication" used by humans, then its meanings will not be limited to logical truth value, because human communication is not limited to a logical calculus. The adverbial clitics $v i$ and $c i$ in literary Italian achieve different communicative effects having to do with Restrictedness of Space. Vi and ci are not synonymous. The demonstrably real patterns in which they participate in actual discourse can be accounted for only if $v i$ and $c i$ are not viewed as interchangeable. And their semantic opposition can be appreciated in the different interpretive effects to which they contribute in actual attested examples. Essential to this understanding is a view of grammar as a tool of subjective human communication in authentic context, and an analytical willingness to abandon the received categories of the linguistic tradition.

\section{Sources of Data}

Berto, Giuseppe. 1951. Il brigante. n.p.: Einaudi.

Calvino, Italo. 1951. Il visconte dimezzato. New York: Appleton, 1968.

Cescatti, Olimpio. 1975. "La vita...." La natura, by Lucrezio, pp. vii-xiii. n.p.:

Garzanti, 4th edition, 1982.

Rigoni Stern, Mario. 1962. Il sergente nella neve: Ricordi della ritirata di Russia.

Torino: Einaudi, 1964. 
Ronconi, Alessandro. 1948. "Lucrezio nel bimillenario." La natura, by Lucrezio, pp. xv-xxix. n.p.: Garzanti, 4th edition, 1982.

Silone, Ignazio. 1937. Pane e vino. Lugano: Capolago.

Tabucchi, Antonio. 1983. Donna di Porto Pim: Ealtre storie. Palermo: Sellerio. Various web sites, with URLs cited.

\section{References}

Calabrese, Andrea. 2002. “I pronomi clitici." In L. Renzi, G. Salvi, and A. Cardinaletti Grande grammatica italiana di consultazione, vol. I, Bologna: Il Mulino. Contini-Morava, Ellen. 1976. "Statistical Demonstration of a Meaning: The Swahili Locatives in Existential Assertions." Studies in African Linguistics 7.2.137-156. Contini-Morava, Ellen, and Barbara Sussman Goldberg (eds.). 1995. Meaning as Explanation: Advances in Linguistic Sign Theory, Berlin: Mouton de Gruyter.

Contini-Morava, Ellen, Robert S. Kirsner, and Betsy Rodríguez-Bachiller (eds.). 2004. Cognitive and Communicative Approaches to Linguistic Analysis. Amsterdam / Philadelphia: John Benjamins.

Davis, Joseph. 2002. "Rethinking the Place of Statistics in Columbia School Analysis." In Reid, Wallis, Ricardo Otheguy, and Nancy Stern (eds.), pp. 65-90.

Davis, Joseph. In press. The Substance and Value of Italian si. Amsterdam / Philadelphia: John Benjamins.

Davis, Joseph, Radmila J. Gorup, and Nancy Stern (eds.). 2006. Advances in Functional Linguistics: Columbia School Beyond its Origins. Amsterdam / Philadelphia: John Benjamins. 
Diver, William. 1995/2012. “Theory.” In Alan Huffman and Joseph Davis (eds.), Language: Communication and Human Behavior. The Linguistic Essays of William Diver, Leiden / Boston: Brill, 2012, pp. 445-519.

García, Erica C. 2009. The Motivated Syntax of Arbitrary Signs: Cognitive Constraints on Spanish Clitic Clustering. Amsterdam / Philadelphia: John Benjamins.

Gorup, Radmila. 1987. The Semantic Organization of the Serbo-Croatian Verb. München: Otto Sagner. (Slavische Beiträge. 214.)

Huffman, Alan. 1977. "Traditional Grammar vs. the French Verb—A Study of the French Compound Verb Tense Auxiliaries: avoir and être." Columbia University Working Papers in Linguistics, vol. 4: 79-125. Reprinted Summer 1978.

Huffman, Alan. 2001. "The Linguistics of William Diver and the Columbia School." WORD 52(1): 29-68.

Huffman, Alan. 2012. "Introduction: The Enduring Legacy of William Diver." In Alan Huffman and Joseph Davis (eds.), Language: Communication and Human Behavior. The Linguistic Essays of William Diver, Leiden / Boston: Brill, 2012, pp. 1-20.

Lepschy, Anna Laura, and Giulio Lepschy. 1988. The Italian Language Today. 2nd edition. New York: New Amsterdam.

Pei, Mario. 1941. The Italian Language. New York: Columbia University Press.

Reid, Wallis. 1978. The Human Factor in Linguistic Analysis: The passé simple and imparfait. Ph.D. dissertation. Columbia University.

Reid, Wallis, Ricardo Otheguy, and Nancy Stern (eds.). 2002. Signal, Meaning, and Message. Amsterdam / Philadelphia: John Benjamins. 
Russi, Cinzia. 2008. Italian Clitics: An Empirical Study. Berlin / New York: Mouton de Gruyter.

Tobin, Yishai. 1994. Invariance, Markedness and Distinctive Feature Analysis: A Contrastive Study of Sign Systems in English and Hebrew. Amsterdam / Philadelphia: John Benjamins.

\footnotetext{
${ }^{i}$ An illustration of an analysis-driven decision to posit homonyms would include a treatment of $c i$ 'us' and $v i$ 'you-pl.' as distinct grammatical signals from those treated here. See below and Davis (in press).

ii Under the heading "Il pronome clitico locativo" 'The locative clitic pronoun,' Calabrese (2002: 559-562), in the Grande grammatica italiana di consultazione, treats only $c i$, not $v i$ at all. That work treats $v i$ only as the plural personal pronoun 'you-pl'; cf. below.

iii In order to eliminate from the search any tokens of cosa as object of a preposition, only the VS order, not the SV order was used; both are common in Italian. The figure for "neither" is the arithmetic difference between the figure for è qualche cosa and the figure for $c^{\prime} / v^{\prime} / v i$ è qualche cosa, or the difference between $\grave{e}$ la/quella/questa cosa and $c^{\prime} / v^{\prime} / v i$ è la/quella/questa cosa, since the latter would be mechanically included in a search for the former. The present tense (è) was searched in order to avoid the issue of grammatical aspect of the past tense; see below. Analogous remarks apply for the following table involving persona.
} 
iv The odds ratio, $\mathrm{OR}$, with a null value of 1.0 indicating no correlation, is provided as the most straightforward measure of the strength of association, with no implications about statistical generalizability to other bodies of discourse. In general, inferential statistics are inappropriate when, as here, a sample cannot be assumed to be representative of some larger population. Particularly, the chisquare test is inappropriate when, as here in connected discourse, tokens cannot be assumed to be independent of each other. See Davis (2002). v The hypothesis makes no prediction regarding the correlations of things and persons with the two meanings (values) within the system, as is done in the two counts to follow. This is possible ground for future research; see the section below. vi On a related note, the position taken in this paper is not that $c i$ is an "including member" of the system. If $c i$ were an "including member," then it would indeed have a meaning of Restrictedness of Space but one that encompassed the entire range from restricted to unrestricted. (Compare Swahili locatives as per Contini-Morava 1976.) Such a relative semantic "imprecision" for $c i$ would be consistent with the observed correlation involving different degrees of attention (cf. Diver 1995/2012: 497-498), but the hypothesis would not be consistent with other observations. vii See Davis (in press) for further on this reconceptualization of verb number. viii Contini-Morava (1976) investigates quantitative facts in Swahili with regard to locatives and grammatical number, but the semantic substance in Swahili has to do with internally "differentiated" space, not externally "restricted" space. ix The rationale behind this prediction assumes the Columbia School position that, at least in languages like Italian (Davis, in press) and Spanish (García 2009: 51) what is 
ordinarily termed the grammatical subject of a finite verb represents the participant in that event that is being placed "in focus," i.e., the participant on whom the reader is to direct the highest degree of attention versus other participants (e.g., represented by oblique clitics) in that event. This hypothesis about the finite verb ending is reminiscent of the traditional definition of the subject as "what the sentence is about" (as opposed to the subject as performer of the action, or as the element of the clause that exhibits syntactic agreement with the verb).

$x$ Because this analysis depends on extensive context, and because the elements analyzed are simply two discrete morphemes, line-by-line glosses are for the most part dispensed with, as are single quotations enclosing translations (which are original to this author).

xi http://www.ilpiaceredileggere.it/Autori/SimonedeBeauvoir/ Memoriadunaragazzaperbene.aspx\#.WOujqRSvPFI, accessed April 10, 2017. xii http://www.giornaledibrescia.it/italia-ed-estero/firma-il-contratto-al-nonomese-di-gravidanza-non-ci-credevo-1.3147611, accessed April 10, 2017. xiii Contini-Morava (1976: 142-143) notes that, in Swahili, the least frequent of the three morphemes found in locative uses is the most frequent in existential uses. She reasons that this reversal is due to the fact that existential contexts, unlike locative contexts, typically do not involve "considerations of a specific, literal place." Though Italian does not exhibit such a reversal of frequencies, and though the semantic substance and the meanings are different from Swahili, the reasoning may help to account for the favored status of $c i$, versus $v i$, in typical existentials in Italian. 
xiv Contrast German es gibt 'it gives' and Spanish hay < CL habet 'it has.' Tobin (1994: 189-305) considers certain expressions involving the Hebrew kan 'here' to be existential.

xv In Davis (in press), as in earlier work, analysis of oppositions of substance, in order to be kept manageable-in order, that is, to have some concrete basis on which to compare examples-require that both forms, even while differing in relative semantic load, systematically share at least one meaning in common. Thus, e.g., the clitics gli, lo, and si by hypothesis all bear a meaning (INNER Focus on participants) that makes them appropriate to refer to true participants in events; they are all opposed in value to the so-called partitive clitic ne (OUTER Focus), for mere bystanders to events. Among those three signals of the meaning INNER Focus, gli (dat.) and lo (acc.) participate in a mutual opposition of value within the substance of Degree of Control (the opposing case roles), while the clitic si sits systematically outside that system - in an opposition of substance with it-bearing no Degree of Control meaning at all (Referents of si are associated with any Degree of Control or none).

${ }^{\text {xvi }}$ In treatments that accept the received categories of active and passive voice, the construction è allungato 'is stretched out' might be labeled an instance of (one form of) the passive voice. Here, as in Columbia School in general, such a priori categories are not assumed; instead, here, as in Davis (in press), following Huffman (1977), forms of the copula are taken at face value, whether they are followed by a participle (allungato 'elongated') or not (e.g., immobile 'motionless'). 